\title{
A serviço do império e da nação: trabalho indípena e fronteiras étnicas no Espírito Santo (1822-1860*)
}

Vânia Maria Losada Moreira* *

Resumo: O artigo procura analisar a organização política e social dos índios da província do Espírito Santo e o processo de recrutamento deles para trabalharem para o Estado, durante a primeira metade do século XIX. São dois os principais objetivos da reflexão: (1) analisar o sistema político-administrativo que controlava o trabalho dos índios, identificando os lugares e tipos de serviços realizados por eles, as principais autoridade civis e militares responsáveis pelas questões indígenas e os temas e questões mais recorrentes levantados pelos próprios índios que estavam submetidos ao "serviço imperial e nacional"; e (2) verificar o impacto desse sistema político-administrativo criado para captar o trabalho indígena na reprodução das fronteiras étnicas entre os índios e os "outros” moradores da província.

Palavras-chave: Índios. Trabalho. Fronteiras étnicas. Governo municipal. Província do Espírito Santo.

Por diferentes meios e argumentos, os índios têm sido excluídos da história. Com a fundação do Instituto Histórico e Geográfico Brasileiro, em 1839, e o desenvolvimento da historiografia propriamente nacional, por exemplo, instituiu-se uma visão

\footnotetext{
* Esta pesquisa conta com o apoio da Faperj.

** Professora-Associada da Universidade Federal Rural do Rio de Janeiro (UFRRJ), Programa de Pós-Graduação em História. E-mail: vania.vlosada@gmail.com.
} 
europeia sobre o Brasil e a sua história, na qual não havia lugar para eles. Francisco Adolfo de Varnhagen frisou, dentre outros pontos, que os índios não eram objeto da história, mas da etnografia (MONTEIRO, J. M., 2001, p. 3), e boa parte da historiografia oitocentista os ignorou, de fato, referindo-se a eles muito mais como obstáculos que "infestavam" as matas e sertões, impedindo o avanço da "civilização" do que como personagens da história pátria.

A renovação historiográfica das décadas de 1930-1940 não resolveu o problema da exclusão dos índios da história nacional, apesar da geração modernista da década de 1920 ter elegido os índios como um dos símbolos da nacionalidade (MOREIRA, 2008, p. 71). Na verdade, agregou ao velho problema outros conteúdos. Um dos historiadores mais representativos do período, autor de uma obra de grande e longa influência, publicada primeiramente em 1942, foi Caio Prado Júnior (1971). Em Formação do Brasil contemporâneo, ele construiu e consolidou alguns argumentos que tornaram a história dos índios desnecessária à efetiva compreensão do Brasil pós-colonial. Postulou que, com exceção dos grupos indígenas que ainda viviam insulados nas matas, especialmente na região amazônica, os demais estavam "extintos", "aculturados" ou "miscigenados" na maior parte do território brasileiro, desde o fim do período colonial (PRADO JÚNIOR, 1971, p. 100). Em outras palavras, os índios não mais interferiam no "sentido da colonização", pois só existiam (transitoriamente) nas franjas periféricas (e desimportantes) do Brasil. A possibilidade de uma história que incluísse os índios foi restringida, desse modo, aos períodos ou lugares mais remotos da colônia. Além disso, a presença dos índios terminava muito rapidamente na história pátria, pois, no pós-contato com "brancos" e "negros", prevalecia, mais cedo ou mais tarde, o desaparecimento dos (verdadeiros) índios em razão das mortes (epidemias, guerras e superexploração do trabalho), da mestiçagem biológica e da aculturação (MOREIRA, 2008, p. 78).

As operações historiográficas que tornaram os índios invisíveis na história representam um tema importante que tem sido analisado por diferentes autores (ALMEIDA, M. R., 2003; CUNHA, 1992; MONTEIRO, J. M., 2001; MOREIRA, 2008). É também 
um dos fundamentos que sustentou um importante movimento de renovação historiográfica no sentido de incluí-los na História do Brasil, cujos marcos mais importantes desse processo foram as publicações do livro Negros da terra, de John Manuel Monteiro (1994) e da coletânea de artigos História dos indios no Brasil, organizado por Manuela Carneiro da Cunha (1992). Desde então, há um crescente interesse pelos índios na História do Brasil, traduzido em novas pesquisas, publicações e congressos, preocupados em recuperá-los não somente onde ou quando eles são maioria ou essenciais, mas também onde ou quando eles são minoria, segundo o ideário de que a historiografia não deve ser apenas o reduto dos "vencedores" ou das "grandes massas anônimas", em um país que se quer construir na linha democrática e plural.

O ponto de partida do presente estudo é a hipótese de que a população indígena é um setor bastante importante para o entendimento da história social do Espírito Santo, durante a primeira metade do Oitocentos, e, mais ainda, que isso pode ser observado na organização e no funcionamento do mundo do trabalho na região. Este artigo procura enfrentar este tema. Para isso, analisa a organização política e social dos índios residentes na vila de Nova Almeida (antiga missão jesuítica dos Reis Magos) e o processo de recrutamento dos índios para trabalharem para o Estado, durante a primeira metade do século XIX.

São dois os principais objetivos da reflexão: (1) analisar o sistema político-administrativo que controlava o trabalho dos índios, identificando os lugares e tipos de serviços realizados por eles, as principais autoridade civis e militares responsáveis pelas questões indígenas e os temas e questões mais recorrentes levantados pelos próprios índios que estavam submetidos ao "serviço imperial e nacional"; e (2) verificar o impacto desse sistema político-administrativo criado para captar o trabalho indígena na reprodução das fronteiras étnicas entre os índios e os "outros" moradores da província.

Para subsidiar a análise dos problemas em foco neste artigo, foi compulsado um conjunto de fontes de natureza bem diversa, como leis, memórias, estimativas estatísticas e relatos de viajantes e naturalistas. Também foi construída uma série documental a partir 
da correspondência oficial entre os presidentes da província do Espírito Santo e as autoridades civis e militares da vila indígena de Nova Almeida, no período entre 1828 e 1853, a partir da qual foi possível identificar práticas governativas, os principais temas relacionados aos índios arrolados na correspondência oficial, os agentes político-sociais que exerciam controle sobre a população indígena, as formas legais ou costumeiras de exercício desse poder, bem como as reivindicações e os tipos de ação realizados pelos próprios índios. A natureza, importância e representatividade da série documental para o estudo da população indígena serão avaliadas mais adiante.

\section{Índios súditos do Estado e índios (relativamente) independentes na história regional}

Apesar dos avanços na compreensão sobre a participação dos índios na História do Brasil, não há como ignorar o poder da inércia que ainda grassa em parte da historiografia regional que, acostumada a interpretar o processo histórico sem os índios, continua reproduzindo o velho hábito, mesmo onde e quando eles eram muitos e imprescindíveis. Não é demais frisar, por isso mesmo, a importância dos índios na formação histórica do Espírito Santo, um lugar, além disso, ainda pouco conhecido pela historiografia contemporânea. Em linhas bem gerais, podem-se afirmar, com poucas chances de erro ou exagero, três dados importantes para nortear a reflexão sobre o desenvolvimento histórico do Espírito Santo.

Primeiro: durante boa parte do período colonial, as reduções e fazendas jesuíticas foram, de longe, os setores mais dinâmicos da sociedade e da economia local e, por isso mesmo, em termos de história social, uma das melhores páginas sobre a capitania ainda são as de Serafim Leite (1945), pois essa obra escapa da narrativa sobre os feitos dos poucos personagens ilustres de uma capitania que nem prosperou nem tampouco foi destruída pelos índios dos sertões. Segundo: a história dos padres e das missões se confunde 
com a história dos índios e, por isso mesmo, o entendimento histórico-social do Espírito Santo colonial passa, necessariamente, pelos índios e sua experiência histórica. Terceiro: a melhor historiografia sobre a região é bastante concorde em afirmar que as grandes mudanças sociais e econômicas do Espírito Santo ocorreram tardiamente no Império e durante os anos da República Velha. A primeira grande transformação foi fruto do desenvolvimento das lavouras de café, principalmente a partir da segunda metade do século XIX, quando foram organizados os planteis de escravos em plena crise do próprio sistema escravista (ALMADA, 1984; SALETO, 1996a). A segunda ocorreu por causa do colapso das plantations cafeeiras, em função da abolição dos escravos, quando foi intensificada a imigração europeia, pulverizada a produção agrícola comercial em pequenas e médias posses ou propriedades e, em razão disso, houve uma expansão da economia cafeeira durante a República Velha (SALETO, 1996a; 1996b).

Assim, no transcorrer de década de 1750, os padres foram expulsos da capitania, as antigas missões foram transformadas em vilas e lugares e os índios foram submetidos, desde então, ao duro sistema governativo do Diretório dos Índios. Mas a despeito dessas importantes transformações, a população e a economia do Espírito Santo, definida muito usualmente como "letárgica", não se alterou de forma dramática até meados da década de 1840 . Afinal, o incremento do ingresso de forâneos (escravos e imigrante nacionais e estrangeiros) e o desenvolvimento da economia cafeeira foram processos que se intensificaram gradualmente a partir da segunda metade do Oitocentos. Os dados sobre a década de 1820 confirmam, aliás, a importância dos índios para o entendimento da história social da província.

De acordo com o presidente provincial Ignácio Accioli de Vasconcellos (1978), em 1824, a província possuía 35.353 almas, divididas em 8.094 brancos, 5.788 índios, 5.601 pardos livres, 3.221 pardos cativos, 2.682 pretos livres e 9.901 pretos cativos. Isso significa que a população livre, formada por 22.165 indivíduos, embora majoritária com relação à população escrava, composta por 13.122 pessoas, era também bastante plural do ponto de vista 
étnico-racial, representando os índios $25 \%$ da população livre da província (ver Tabela 1 e Gráficos 1 e 2).

Mas ainda, se confrontarmos os dados fornecidos por Vasconcellos com outro produzido por Guido T. Marlière, na mesma década, sobre a população de índios tribalizados e relativamente independentes que viviam no vale do rio Doce, entre os quartéis de Minas Gerais e do Espírito Santo, podemos construir um quadro mais realista sobre o que era o Espírito Santo na primeira metade do Oitocentos. Marlière ponderou, em 1827, que os índios perfaziam aproximadamente 20 mil indivíduos, acrescentando, além disso, que contar índios nas matas e calcular formigas em um formigueiro eram tarefas bem semelhantes (MATTOS, 2004, p. 116). Acrescentese a essa informação o fato de que estão fora desse número os índios que viviam nas fronteiras do Espírito Santo com o Rio de Janeiro (puris, coroados e botocudos) e os que viviam nas fronteiras entre o Espírito Santo e a Bahia (botocudos, pataxós, dentre outros). Os vizinhos mais próximos dos capixabas não eram, portanto, os concidadãos da Corte, de Minas Gerais ou da Bahia, mas a população indígena de diferentes grupos étnicos, muitos deles, ademais, em guerra com a população local. Os Gráficos 3 e 4 ilustram os argumentos aqui levantados.

Os números ilustrados nos gráficos são aproximações grosseiras da realidade demográfico-social do Espírito Santo e dos sertões e florestas adjacentes, mas possuem o mérito de terem sido colhidos em um mesmo período histórico, refletindo, por isso mesmo, os erros, os acertos e as concepções de mundo mais correntes daquele momento. Observando-se o Gráfico 3, portanto, entende-se com mais rapidez por que Francisco Adolfo de Varnhagen (1851 apud MOREIRA NETO, 2005, p. 338) se irritava tanto com o Espírito Santo, a incômoda província fronteiriça à Corte, cheia de índios "selvagens"! Além disso, homens como ele, de gabinete, não viam muito diferença entre os "selvagens" da mata e os "semisselvagens" que estavam sob a autoridade do império, embora muitos deles estivessem vivendo, há várias gerações, sob o governo luso-brasileiro.

Para homens como Ignácio Accioli de Vasconcellos, que governou a província do Espírito Santo entre fevereiro de 1824 e novembro de 1829, a diferença entre índios "civilizados" e "selvagens" 
era clara, pois frequentemente utilizavam-se aqueles para o combate ou "amansamento" destes. Homens como ele certamente também sabiam os limites de tais diferenças, pois o trânsito de índios do sertão para a província e, inversamente, de índios das vilas para os sertões era intenso e difícil de ser controlado. O Gráfico 4 procura ilustrar, portanto, outra realidade social do Espírito Santo: a necessidade de governar uma importante população indígena em diferentes estágios de contato e de transculturação, por meio de regras legais ou costumeiras, artifícios e instituições nem sempre iguais. Mais ainda, em razão do fato de os "índios civilizados" representarem $25 \%$ da população livre da província, também não se deve estranhar, finalmente, a presença dos índios na vida social, política e econômica local.

Em 1828, por exemplo, Vasconcellos expediu ofício ao capitão-mor da vila de Nova Almeida, listando os índios jornaleiros que deixavam o trabalho na Diretoria do Rio Doce para regressarem à vila, solicitando, além disto, outros 14 índios para rendê-los no serviço. ${ }^{1}$ Pouco depois, o mesmo presidente escreveu ao sargento-mor do Regimento Norte pedindo duas índias que fossem "desembaraçadas" para trabalharem na Santa Casa de Misericórdia, para cuidar dos "expostos", recomendando ainda que elas fossem avisadas de que seriam "bem tratadas" e receberiam "gratificação". Tal como esses documentos, existem muitos outros nos arquivos atestando um fato ainda não plenamente estudado e compreendido pela historiografia: o sistema político e administrativo organizado para captar o trabalho indígena exigido pelo Estado, e que eles cumpriam na rubrica de "serviço imperial e nacional". Nas páginas que se seguem, analiso a legislação que dava sustentação política e jurídica à exploração do trabalho indígena pelo Estado.

\section{Legislação e fronteiras étnicas}

Informações qualitativas deixadas por viajantes que passaram pelo Espírito Santo, na segunda década do século XIX, como Auguste de Saint-Hilaire (1974) e o bispo visitador do Rio de Janeiro, 
D. José Caetano da Silva Coutinho (2002), são bastante explícitas em atestar duas situações importantes na capitania nesse período. Em primeiro lugar, as narrativas desses observadores atentos asseguram que os índios ocupavam, no início do Oitocentos, senão todos, pelo menos uma parte dos postos da república nas vilas indígenas de Nova Almeida (antiga missão dos Reis Magos) e Benevente (antiga missão de Nossa Senhora de Reritiba) (COUTINHO, 2002, p. 87; SAINT-HILAIRE, 1974, p. 65).

Não é demais lembrar, a propósito desse assunto ainda pouco conhecido pela literatura não especializada, que o alvará de 7 de junho de 1755 estimulou e deu preferência aos índios na ocupação dos cargos de vereadores e oficiais da Justiça em suas respectivas vilas (SAMPAIO, 2001, p. 113). O sistema político-administrativo, conhecido como Diretório dos Índios (1757-1798), ${ }^{3}$ introduziu, no entanto, a figura tutelar dos diretores sobre os índios e, na opinião de diferentes autores, isso comprometeu o princípio do autogoverno dos índios, que, supostamente, seria viabilizado pela subordinação política deles à autoridade das câmaras, cujos vereadores, juízes e oficiais seriam, de preferência, índios (SAMPAIO, 2001, p. 250).

A abolição do Diretório dos Índios, por meio da carta régia de $1798,{ }^{4}$ tornou mais factível, do ponto de vista legal, o proclamado governo dos índios pelas câmaras, igualando-os, nesse aspecto, aos demais vassalos livres do império português, que não tinham diretores (tutores). Mais ainda, embora a nova lei não recomendasse dar nenhuma preferência aos índios na ocupação dos cargos da república, deixava bastante claro, contudo, que eles continuavam bastante aptos ao exercício daqueles cargos, desde que tivessem competência para isso. Portanto, não se deve estranhar que os índios tenham sido vereadores, juízes e capitães-mores de ordenança de suas respectivas vilas, tal como, aliás, acontecia nas vilas do Espírito Santo, segundo as narrativas de Saint-Hilaire e D. Coutinho. Além disso, ambos também descrevem a existência de um sistema bastante coercitivo de obtenção do trabalho dos índios nas vilas e lugares indígenas, controlado no topo pelos governadores da capitania (COUTINHO, 2002, p. 89; SAINT-HILAIRE, 1974, p. 69). 
Correlacionando esses testemunhos e a legislação indigenista do período, pode-se inferir que o sistema de exploração da força de trabalho dos índios na capitania do Espírito Santo foi organizado segundo as diretrizes do Diretório dos Índios e, posteriormente, reorientado segundo as novas regras instituídas pela carta régia de 1798. Assim, com a extinção do cargo de Diretor de Índios pela lei de 1798, foram transferidas para as câmaras não apenas a tarefa de governar os índios, mas também a função de gerir a estrutura montada anteriormente para captar o seu trabalho. Note-se, além disso, que a situação dos índios do Espírito Santo na época das descrições feitas por D. Coutinho e Saint-Hilaire assemelha-se muito ao que acontecia com os índios do Rio Negro, Pará e Amazônia, casos observados e estudados por Patrícia Sampaio (2001, p. 236).

Mais ainda, o modelo governativo instituído pela carta régia de 1798 teve longa duração entre os índios do Espírito Santo, pois continuou operativo na região mesmo depois da Independência, sendo bastante acionado até 1840. ${ }^{5}$ Isso é um dado importante, pois demonstra que a carta régia de 1798 foi fundamental não apenas para as províncias do Norte, como parece acreditar Patrícia Sampaio (2001, p. 218), mas talvez para muitas outras regiões onde, na longa duração de seu desenvolvimento, foi expressiva a população de índios integrados ao sistema social, tal como era o caso também do Espírito Santo.

Desde as reformas de Pombal, o discurso oficial insistiu sobre a necessidade de promover a equiparação jurídica e política de "índios" e "brancos" e, por isso mesmo, Carlos de Araújo Moreira Neto (2005, p. 233) se referiu à legislação pombalina como um "esforço de 'integração' e de 'nacionalização' dos índios”. A carta régia de 1798 seguiu, nesse aspecto, a mesma direção da legislação pombalina sobre os índios, acabando com a figura tutelar do diretor de índios, segundo o argumento de que isso era necessário para estabelecer a igualdade entre os vassalos. Assim, os índios deveriam ser tratados e governados do mesmo modo que os demais súditos, isso é, não ter "diretores" e submeter-se ao governo da câmara, como todo e qualquer outro vassalo. Em outras palavras, entre a carta régia de 1798 e a promulgação do Regulamento das Missões de Catequese 
e Civilização dos Índios, em 1845, que recriou a figura tutelar dos diretores de índios, vigorou, ao menos do ponto de vista legal, o autogoverno dos índios que, isentos de tutela, poderiam ser juízes e vereadores de suas respectivas câmaras e governar seus pares (CUNHA, 1992, p. 152). Entenda-se por autogoverno" dos índios, portanto, além da extinção da tutela dos "diretores", a subordinação dos índios ao governo da câmara, cujos oficiais poderiam ser índios ou brancos. ${ }^{6}$

A lei não basta, contudo, para criar ou abolir uma determinada situação social, embora possa, como se sabe, contribuir numa ou noutra direção. No campo das relações interétnicas que, efetivamente, vigoravam na colônia, a carta régia de 1798 teve, na realidade, um impacto ambíguo, pois favoreceu tanto a superação das diferenças entre os "índios" e os "outros" vassalos como a reprodução das fronteiras étnicas entre eles. Nas páginas que se seguem, procurarei destrinchar o funcionamento do sistema de captação do trabalho indígena, durante o regime imperial, nas vilas e lugares do Espírito Santo. Mais ainda, tentarei demonstrar que, principalmente onde o trabalho indígena era mais cobiçado do que suas terras, como aconteceu em algumas partes da província do Espírito Santo na primeira metade do século XIX, o sistema político e administrativo, criado à sombra da carta régia de 12 de maio de 1798, terminou por estimular e reproduzir as fronteiras étnicas entre os "índios" e os "outros" moradores da província.

\section{Estado e trabalho indígena}

$\mathrm{Na}$ correspondência oficial entre os presidentes da província do Espírito Santo e as autoridades civis e militares da vila de Nova Almeida, mantida no período entre 1828 e 1853, foi identificado um universo de 85 documentos nos quais os índios são citados textualmente. Esses documentos foram tirados de quatro livros diversos. ${ }^{7}$ Do livro 171, foram compulsados 64 documentos com datas-limite entre 7 de maio de 1828 e 20 de novembro de 1837 , que representam aproximadamente $41,5 \%$ da correspondência total 
registrada no período. ${ }^{8}$ Nos outros livros, a frequência de correspondências na quais os índios são citados de forma explícita cai vertiginosamente, e as possíveis razões disso serão tratadas ao longo do artigo. Por hora, importa registrar que no livro 172 foram compulsados 13 documentos, com datas-limite entre 2 de fevereiro de 1838 e 19 de agosto de 1842, representando, aproximadamente, $11,5 \%$ da correspondência total; que no livro 181 foram encontrados seis documentos, com datas-limite entre 11 de março de 1848 e 17 de março de 1851, representando 3\% da correspondência total; e que no livro 182 foram compulsados dois documentos, com dataslimite entre 30 de abril de 1853 e um documento posterior não datado, representando $2,6 \%$ da correspondência total.

Importante frisar, além disso, a importância da correspondência entre a presidência da capitania e as autoridades civis e militares de Nova Almeida para o estudo dos índios. Pois, como observei anteriormente, entre 1798, com a extinção do Diretório dos Índios, e 1845, com a aprovação pelo governo de D. Pedro II do Regulamento de Catequese e Civilização dos índios, vigorou o governo dos índios pelas câmaras, por meios dos oficiais civis e militares das vilas. Essa documentação é, portanto, uma das mais diretas que existem sobre os índios desse período, e foi produzida, ademais, no calor da ação política e social. Também observei que tais oficiais civis e militares das vilas poderiam ser índios ou não. Infelizmente, contudo, as informações da série documental não permitem que seja apurado se os oficiais civis e militares vinculados à Câmara de Nova Almeida e citados na documentação eram índios, brancos, pardos, pretos ou mestiços. Sabe-se, no entanto, que eram necessariamente homens livres e que existem boas chances de parte deles serem índios, pois era composta de índios a maior parte dos oficiais no começo do século, tal como atestaram Saint-Hilaire (1974) e D. Caetano Coutinho (2002).

A partir da série, procurei verificar, ao longo do período, os principais temas presentes na correspondência oficial (ver Tabela 2); as autoridades responsáveis pelos assuntos relativos aos índios em Nova Almeida, isto é, aqueles agentes civis ou militares da vila para quem os presidentes da província remetiam ordens, instruções ou outro tipo de demanda (ver Tabela 3); e, cruzando os dados 
das Tabelas 2 e 3, foi possível também identificar quais os assuntos tratados mais amiúde por cada autoridade da vila durante o período em foco (ver Tabela 4). Nos limites desta reflexão, contudo, serão apenas analisados os aspectos centrais da governança dos índios, com vistas a captá-los para trabalharem para o Estado.'

$\mathrm{Na}$ Tabela 2, pode-se observar que o assunto mais tratado na documentação foi sobre o trabalho indígena (58,8\%), seguido bem de longe pelas questões relativas às suas terras $(23,5 \%)$, pelas reivindicações feitas pelos próprios índios $(5,9 \%)$ e por um conjunto variado de questões que foram agrupadas no descritor "Outros" $(11,7 \%)$. Note-se que na composição do assunto "terra" foram incluídos alguns documentos de índios, reivindicando direitos com relação às terras que ocupavam e que poderiam ser dispostos também na linha "Reivindicações dos índios". Para evitar distorções, optei por mantê-los na linha "Terra". Porém, na tabulação dos dados sobre tipos de ação dos índios, que operacionaliza, entre outros dados, aqueles referentes às suas reivindicações, foram incluídas no descritor "Reivindicações dos índios" também aquelas demandas indígenas vinculadas ao tema "terra", tal como explicitam as notas explicativas da Tabela 7.

A Tabela 5 organiza os principais tipos de ocorrência no assunto "trabalho" e o Gráfico 8 procura visualizá-los de forma mais satisfatória. Note-se, além disso, que cada documento pode ter mais de uma ocorrência dentro do assunto "trabalho". Assim, nas 50 correspondências classificadas como pertencendo ao assunto "trabalho", foram identificadas 58 ocorrências ligadas ao tema "trabalho". A solicitação de índios para a prestação de serviço ao Estado ou para render outros índios que já estavam trabalhando para o "império e a nação" é, disparado, a principal ocorrência $(70,7 \%)$. A título de exemplo, vale citar a correspondência do presidente da província, José Francisco de Andrade e Almeida Monjardim, que, em 2 de abril de 1830, demandou ao capitão-mor de Nova Almeida sete índios para substituir os que estavam com o tempo de trabalho vencido. ${ }^{10}$ Ou ainda, a correspondência de 26 de janeiro de 1830, do Visconde da Vila Real de Praia Grande, solicitando oito índios para render os que se encontravam no "serviço imperial e nacional". ${ }^{11}$ 
A segunda ocorrência mais frequente refere-se aos pagamentos já realizados ou que deveriam ser feitos a bem dos índios (13,8\%). Assim, em 17 de setembro de 1828, o presidente Ignácio Accioly de Vasconcellos mandou um aviso ao juiz ordinário de Nova Almeida, ordenando que o administrador da passagem da vila pagasse o jornal devido aos índios. ${ }^{12} \mathrm{Ou}$ ainda, a correspondência expedida pelo mesmo presidente ao capitão-mor da vila de Nova Almeida, mandando pagar os vencimentos dos índios que estavam servindo na Diretoria do Rio Doce e orientando que eles deveriam permanecer nesse serviço por seis meses. ${ }^{13}$ Esse documento é, ademais, o único da série que indica o tempo de serviço que os índios deveriam prestar ao "império e à nação". Nos demais, não há como auferir o tempo de serviço combinado entre as partes nem tampouco o tempo de serviço efetivamente prestado pelos índios.

As notificações de que índios fugiram de seu posto de trabalho, com ou sem mandato de prisão, por abandono do serviço imperial e nacional, formam a terceira ocorrência mais frequente $(6,9 \%)$. Seguem-se a essa as correspondências que visam organizar o sistema de recrutamento dos índios (3,4\%). Nesse caso, destaca-se a preocupação do vice-presidente José Francisco de Andrade e Almeida Monjardim que, em 19 de agosto de 1830, mandou ao capitão-mor da vila a ordem expressa de que, sendo ele "capitãomor dos mesmos índios", deveria zelar para que "quando lhe exigir gente, seja sempre recolhido de todos aqueles lugares [i.e., Nova Almeida e Aldeia Velha], porquanto, todos devem concorrer para o serviço público", acrescentando ainda não ser justo que só o distrito das Águas desse seus índios. ${ }^{14}$

Essa correspondência é bem interessante. De um lado, testemunha a existência de um sistema de recrutamento e de rodízio de índios para o trabalho que envolvia diferentes lugares. De outro, também testemunha, nas entrelinhas, as relações de poder entre índios, capitão-mor e as autoridades provinciais. Ou seja, o poder do capitãomor, que, ao que tudo indica, era um índio principal que podia escolher quais dos "seus índios" seguiriam para o trabalho, liberando certos distritos ou grupos e alistando e prejudicando outros. Mas também o poder de negociação dos índios, que tinham condições, entre outras características, de recorrer ao presidente e impetrar 
reclamações, pois, certamente, foi em razão de reclamações vindas dos índios do distrito das Águas que o presidente Monjardim passou a recomendar ao capitão-mor maior equidade no "recolhimento" de "sua gente" para o serviço imperial. As outras ocorrências são variadas $(5 \%)$ e referem-se, por exemplo, a doenças ou maus-tratos ocorridos entre índios que prestavam o serviço imperial e nacional.

Os tipos de trabalho realizados pelos índios ou os lugares onde tais serviços eram feitos podem ser consultados na Tabela 6 e melhor visualizados no Gráfico 9. A Tabela 6 trabalha com um universo de 50 ocorrências sobre a prestação de serviço para o Estado, em que 22\% delas usam as expressões genéricas "serviço e imperial e nacional" e 10\%, "serviço público" ou serviço em "obras públicas". Somando-as, tem-se que 32\% das ocorrências de solicitação de índios para prestarem serviço ao Estado não indicam o local ou a função a ser exercida por eles. Mas se sabe que eles tanto poderiam ser indicados para algum lugar ou posto na província, situação mais frequente, como também poderiam ser enviados para a corte ou para onde mais se julgasse conveniente.

As demais ocorrências especificam a função ou o lugar de trabalho. Assim, tomando como base as 50 ocorrências, 16\% delas indicam a Diretoria do Rio Doce, que era uma instituição voltada para a "pacificação" e o aldeamento dos índios botocudos da província. Em outras palavras, os índios (civilizados/cidadãos) de Nova Almeida eram recrutados para trabalhar no aldeamento dos índios "selvagens" do rio Doce e exerciam, ali, diferentes tarefas, mas, principalmente, os serviços na agricultura, na construção civil e na defesa contra os ataques dos botocudos, não permitindo que eles entrassem de modo hostil nas áreas povoadas da província e nem tampouco que grupos arredios roubassem plantações e destruíssem estabelecimentos no próprio rio Doce. Doze por cento referem-se ao trabalho prestado no Forte São João e Passagens e 10\% indicam o Escaler do Governo e Passagens. Em ambos os casos, os índios exerciam, principalmente, a função de remeiros e, por isso, foram agrupados no Gráfico 9, perfazendo $22 \%$ das ocorrências. Oito por cento ocorrências citam o corte de madeira e a construção naval, e $6 \%$ referem-se ao combate de quilombos ou à captura de escravos fugitivos. 
Em 27 de novembro de 1828, por exemplo, o presidente Vasconcellos solicitava ao sargento-mor, comandante do Regimento Norte, Antônio Bonifácio Pereira, que mandasse dez índios, "dos mais robustos e valentes", acompanhados de suas armas, se as tivessem, para combater os "quilombos de negros fugidos que se sabe vagar por essas cidades" ${ }^{15}$ Por fim, as ocorrências classificadas em "outras" perfazem 16\% do total e referem-se a um universo bem variado, desde a solicitação de índias "desembaraçadas" (i.e., solteiras ou sem filhos) para trabalhar na Santa Casa de Misericórdia com os "expostos" (i.e., crianças abandonadas) até a solicitação de índios para fazer serviços de correio. ${ }^{16}$

\section{Governança e gestão do trabalho indígena}

O Gráfico 5 visualiza a evolução dos dois principais assuntos tratados na correspondência oficial entre os presidentes da província e as autoridades da vila indígena: trabalho e terra. Mostra que o tema "trabalho", embora dominante na correspondência oficial, foi saindo do foco das autoridades conforme os anos se passavam. Isso fica demonstrado na queda vertiginosa da frequência desse assunto na correspondência oficial até o seu total desaparecimento, a partir do subperíodo 1840-1842. Desde então, o assunto mais frequentemente tratado na correspondência oficial são temas relacionados às terras dos índios. Entretanto, como o Gráfico 5 bem ilustra, esse assunto não se tornou uma prioridade para as autoridades, pois, apesar de se tornar o assunto mais em voga, sua frequência na correspondência entre os presidentes das províncias e as autoridades civis e militares de Nova Almeida é muito menor se comparada com o assunto "trabalho", que tanto interesse despertou entre as autoridades da província.

A redução contínua da frequência do assunto "trabalho" na correspondência mantida entre o presidente da província e as autoridades da vila, até o seu total desaparecimento, é um dado bastante importante. Sinaliza o progressivo desuso de um sistema de governo criado ainda no período colonial e cujo principal objetivo era organizar os índios para trabalharem para o Estado e os particulares. 
Note-se, contudo, que é o sistema governativo para gerir o trabalho dos índios que entra em colapso a partir da década de 1840, não o costume de os índios prestarem serviços ao Estado e aos particulares nem tampouco a subordinação política deles ao governo municipal. Em 1856 e em 1857, por exemplo, ainda foram encontrados registros textuais sobre o recrutamento dos índios da região de Nova Almeida para realizarem serviços públicos na província, de um modo bastante próximo ao sistema normatizado pela carta régia de 1798. No relatório provincial de 1856, referente à seção "Colonização", registravase que tendo

[...] o governo imperial resolvido definitivamente criar uma colônia nas margens do rio Santa Maria mandei [...] examinar aqueles lugares pelo engenheiro João José Sepúlveda e Vasconcellos [...] ordenei ontem ao mesmo engenheiro que partisse para aquele ponto com 26 trabalhadores, que mandei engajar na vila de Santa Cruz, a fim de fazer as picadas necessárias, marcar o centro da povoação, e medir os prazos ao menos para as primeiras cinquenta famílias, que devem chegar com brevidade a este porto. (RELATORIO..., 1856, p. 12).

Não é demais esclarecer que Santa Cruz era um distrito que surgiu a partir de seu desmembramento de Nova Almeida. Os "trabalhadores" ali contratados, em1856, não foram devidamente identificados no relatório oficial desse ano. O mesmo não ocorreu, contudo, no relatório de 1857, onde eles aparecem cabalmente definidos como "índios". Desse modo, a abertura do novo núcleo colonial marchava lentamente pela "dificuldade de obter-se trabalhadores ativos em número suficiente - tendo por isso continuado a servir-me de alguns índios de Santa Cruz que só se prestavam a esse serviço com a condição de serem substituídos por outros em um prazo que não devesse exceder de um até dois meses" (RELATORIO..., 1857, p. 13).

Resumindo, o desaparecimento do assunto "trabalho" na correspondência oficial não significa que os índios ficaram livres da obrigação de trabalharem para o Estado e os particulares. O trabalho 
continuou, mas os constrangimentos legais e as formas de organizar a gestão da mão de obra indígena tornaram-se progressivamente outras. Dentre os novos constrangimentos legais criados para forçar os índios a ingressarem no mercado de trabalho, destaca-se o recrutamento militar compulsório (MOREIRA, 2005, p. 114). O recrutamento era justificado, além disso, não tanto no fato de eles serem "índios", mas segundo o argumento de que os presos para o recrutamento eram "vadios". Desse modo, índios que não tivessem família e um estabelecimento próprio (plantação), considerado razoável pelas autoridades, ou que não tivessem um "amo" ou "patrão", caíam invariavelmente nas malhas do recrutamento por serem "vadios" e passavam a servir na província ou na corte do Rio de Janeiro (MOREIRA, 2005, p. 117).

$\mathrm{Na}$ Tabela 3, pode-se consultar quais foram os destinatários das ordens e recomendações dos presidentes da província ao longo do período entre 1828 e 1853. Os capitães-mores receberam 40\% das correspondências, seguido pelos juízes de paz, que receberam $27 \%$, e pela câmara, que ficou com $16,5 \%$ do total da correspondência oficial. As demais autoridades dividem entre si os restantes 16,5\% da correspondência oficial do período em foco. A Tabela 4 estabelece a correlação entre temas e autoridades e pode-se verificar que, entre as três autoridades mais acionadas pela presidência da província, os capitães-mores tratavam fundamentalmente de temas relativos ao trabalho, a câmara só foi acionada para resolver questões de terra e os juízes de paz tinham uma agenda bastante diversificada, tratando além das questões de terra e trabalho, também de um conjunto variado assuntos (prisão, investigação de delitos, etc.).

O Gráfico 7 procura ilustrar a relação entre assuntos e autoridades e trabalha com números absolutos. Assim, das 34 correspondências recebidas pelos capitães-mores, 31 relacionavam-se com o tema "trabalho". Em outras palavras, 91,1\% da correspondência oficial entre a presidência da província e os capitães-mores eram para solicitar índios para o serviço imperial e nacional ou outros temas vinculados ao mundo do trabalho. Com relação à câmara, $100 \%$ das correspondências recebidas tratavam de assuntos de terra, pois, todas as 14 correspondências a ela enviadas eram sobre esse tema. Já os juízes de paz receberam ao todo 23 correspondências, 
das quais oito eram sobre trabalho $(34,7 \%), 4$ sobre terras $(17,3 \%)$ e 11 sobre assuntos variados (47,8\%).

Dentre as questões tratadas entre a presidência e o os juízes de paz classificados em "Outros assuntos", destacam-se as correspondências relativas ao sequestro de crianças índias de seus pais. Em 15 de dezembro de 1829, por exemplo, o presidente da província, Visconde de Praia Grande, questionou severamente o juiz de paz, perguntando-lhe "por que ordem tem tirado do poder das índias seus filhos menores e que destino estava dando a eles?" ${ }^{17}$ Outro ofício do mesmo presidente mandava o juiz de paz Vicente de Jesus devolver as "crianças índias" para suas respectivas mães. Mais ainda, advertia-o enfaticamente que cessasse esse tipo de prática, segundo a justificativa de que os índios também eram "súditos do Imperador". ${ }^{18}$

A prática de tirarem-se as crianças índias de seus pais e cedê-las a terceiros vigorava especialmente entre os indígenas recentemente destribalizados e classificados como "selvagens" pelas autoridades. Amparava-se na legislação orfanológica e justificava-se segundo o argumento de que os tutores de tais índios (crianças ou adultos) iriam educá-los, cristianizá-los e civilizá-los e, em troca, poderiam dispor de seu trabalho a título de ressarcimento pelos gastos efetuados (CUNHA, 1992, p. 147). Em uma passagem da narrativa de Auguste-François Biard sobre a viagem que fez ao Espírito Santo, em 1858, pode-se ler:

Desta vez ele [o anfitrião de Biard] me cedeu um dos seus índios. Digo assim porque é costume na província do Espírito Santo tomar-se conta dessas criaturas desde meninos, embora pertençam a alguma instituição orfanológica; comprometem-se a criá-los e vigiá-los até uma certa idade, não como escravos, mas apenas como empregados. (MOREIRA, 2001, p. 99).

Apesar de legal, a tutela orfanológica não deixa de ser uma forma disfarçada de trabalho compulsório imposto aos índios, muito próxima, ademais, à “administração particular" impingida aos índios em São Paulo, durante a maior parte do período colonial, estudada 
por John Manuel Monteiro (1994, p. 137). Por isso, as reclamações dos índios de Nova Almeida contra essa prática é bem interessante, pois demonstra a luta deles para garantir a própria liberdade e a dos filhos, e o conhecimento que tinham de seus direitos. Não é demais lembrar que os índios de Nova Almeida foram agraciados pela lei de 6 de junho de 1755, conhecida como a Lei das Liberdades (DOMINGUES, 2000, p. 25), e disso eles não se esqueciam. Assim, embora muitos índios botocudos do rio Doce fossem entregues aos particulares, de acordo com a lei de 27 de outubro de 1831 que concedeu a liberdade a todos os índios cativados durante a vigência das guerras joaninas de 1808 e 1809, e estendeu-lhes, além disso, a condição de órfãos (CUNHA, 1992, p. 148) -, o mesmo não ocorria com igual facilidade entre os índios de Nova Almeida. Afinal, os registros documentais demonstram que eles reclamavam veementemente quando isso acontecia e, mais ainda, eram ouvidos e atendidos pelas autoridades superiores nessa questão particular, por serem reconhecidos como "súditos livres" do Estado.

Note-se, ainda, que os capitães-mores simplesmente deixam de receber qualquer ofício da presidência da província a partir do subperíodo 1834-1836 (ver Tabela 3). E isso por uma razão bem simples: em 1831, é criada a Guarda Nacional, extinguindo-se os corpos de ordenança e, por extensão, também o cargo de capitãomor das ordenanças. De qualquer modo, enquanto vigoraram as ordenanças, o principal responsável pela organização e pelo controle do trabalho dos índios foi o capitão-mor da vila. Ademais, com fim das ordenanças e do posto de capitão-mor, quem passou a selecionar os índios para o serviço imperial foram os juízes de paz. Também isso não foi por acaso, pois as ordenanças foram substituídas pela Guarda Nacional, a milícia cidadã do império, e a Guarda Nacional estava subordinada aos juízes de paz, aos juízes criminais, aos presidentes das províncias e ao ministro da Justiça (URICOECHEA, 1978, p. 135).

Não cabe aqui discutir os novos objetivos vinculados à criação da Guarda Nacional. Por hora, basta lembrar algumas continuidades importantes entre ela e as ordenanças, especialmente o trabalho prestado pelos guardas nacionais ao Estado que, em tudo, é comparável ao trabalho que antes esses homens deviam ao Estado na qualidade 
de membros das ordenanças de suas respectivas vilas (URICOECHEA, 1978, p. 150). Assim, os dados disponíveis apontam que os índios de Nova Almeida, depois de extintas as ordenanças, continuaram sob a jurisdição do governo local das câmaras, e no tocante à organização e distribuição deles para o trabalho, ficaram sob o controle do juiz de paz, que também tinha jurisdição e autoridade sobre a Guarda Nacional.

O Gráfico 6 visualiza a evolução temporal das correspondências recebidas pelos capitães-mores, juízes de paz e pela câmara. Note-se que o declínio das correspondências recebidas pelo capitão-mor se dá concomitantemente a um pequeno aumento das correspondências recebidas pelos juízes de paz, que, a partir de 1831, passam a receber as ordens para enviar índios ao serviço imperial e nacional. O ofício enviado pela presidência da província ao juiz de paz Dionísio Álvaro Ramos, em 9 de julho de 1836, é bem ilustrativo sobre as novas funções atribuídas ao cargo que ele ocupava. Informou, pois, que os índios José Manoel dos Santos, Manoel Joaquim, Manoel Victoriano, Julião Baptista, Ignácio Francisco, Domingos dos Ramos e Ângelo da Victoria estavam regressando à vila depois de prestarem serviços na construção da casa para a administração das rendas provinciais, e ainda ordenou que o juiz providenciasse outros seis índios para substitú-los no mesmo serviço. ${ }^{19}$ Mais ainda, em 20 de novembro de 1837, o presidente José Thomas Nabuco de Araújo reconhecia, de modo bastante enfático, o empenho com que o juiz de paz recrutava índios para o serviço imperial. Por isso mesmo, solicitava a ele o "maior número possível de índios". ${ }^{20}$

\section{Os índios em ação: prioridades e negociação}

A Tabela 7 informa sobre os tipos de ação realizada pelos índios que podem ser inferidos a partir da correspondência oficial entre os anos 1828 e 1853. Em um total de 25 ocorrências identificadas na série documental, duas referem-se a rebeliões $(8 \%)$, quatro são sobre fugas ou deserção dos postos de trabalho $(16 \%)$ e as demais são requerimentos formalmente apresentados pelos índios (44\%) ou são queixas de índios que aparecem de modo indireto 
na documentação (32\%). Importante esclarecer a diferença estabelecida entre "requerimentos" e "queixas". Em certas correspondências, fica bastante evidente que a preocupação do presidente foi motivada por queixas ou demandas de índios. Como não há, contudo, um modo seguro de auferir se se tratava de requerimentos formais impetrados por eles, arrolaram-se esses documentos na rubrica "queixas". Os requerimentos, ao contrário, são queixas formalizadas nos canais institucionais da vila e da província. Esse é um dado muito importante. Sinaliza, dentre outros itens, que os índios souberam aproveitar as oportunidades abertas pelo fim da tutela e pelo autogoverno, pois a participação deles nos postos da república como juiz, vereador, capitão-mor ou sargento-mor, por exemplo, parece ter facilitado a tramitação legal de suas reivindicações e aspirações.

No Gráfico 10, que ilustra os dados da Tabela 7, optei por somar as queixas $(32 \%)$ e as representações formais (44\%) por se tratarem, na prática, de um mesmo tipo de ação baseada na estratégia de negociar as demandas e os conflitos pelos canais formais do período. É importante frisar, portanto, que, durante o autogoverno dos índios de Nova Almeida, 76\% das ações realizadas por eles são reclamações e reivindicações expressas de maneira formal ou informal nos canais da administração. Ou seja, as reivindicações feitas diretamente ao presidente da província foram, de longe, a estratégia política mais utilizada por eles.

Entre as representações ou queixas encaminhadas pelos índios, seis referem-se a conflitos de terra, quando os índios pedem a devolução das terras das quais foram desapossados ou solicitam que não sejam perturbados na posse de seus terrenos. Bem exemplar desse tipo de requerimento feito pelos índios é o caso narrado em ofício datado de 19 de agosto de 1842. Nesse documento, o presidente da província, João Lopes da Silva, informa ao juiz de paz que recebeu uma representação dos índios Miguel da Silva e Antônio das Neves, que reclamavam "das violências [e] arbitrariedades contra eles praticadas por Victorino José Pinto, o qual confiado na proteção de algumas autoridades e outras pessoas, tem [perturbado] a posse dos índios das terras que lhes foram concedidas". O presidente ainda ordenou que Victorino assinasse "termo de não incomodar 
mais os índios no gozo de suas terras", afirmando ainda que o juiz seria responsabilizado caso a ordem não fosse cumprida. ${ }^{21}$

Entre os demais requerimentos e as queixas, cinco reclamavam sobre o sequestro de filhos, isto é, procuravam garantir o direito à liberdade dos filhos; seis, contra o comportamento violento de autoridades ou moradores; e dois, contra os procedimentos de recrutamento de índios para o serviço imperial. Uma última correspondência manda que seja assinado um "termo de bem viver" entre os índios e um morador da região. Não há como saber o motivo do conflito que estava em pauta, mas apenas especular que, possivelmente, tratava-se de litígios por terras, tendo em vista o crescimento desse tipo de problema na região.

Enfim, os dados mostram que os problemas de terra, os sequestros de filhos (garantia da liberdade) e os atos de violência são os três motivos básicos que sustentam as queixas e representações dos índios. Por exemplo, em 23 de agosto de 1838, o presidente João Lopes da Silva informava ao juiz de paz que havia recebido o requerimento do índio José Bernardino e pedia explicações circunstanciadas sobre o assunto, advertindo-o que "não pode e nem deve tirar os indígenas do poder dos pais ou daqueles que os tenham criado para dá-los a terceira pessoa, não havendo melhoramento de condição, como no caso presente". ${ }^{22}$

Também bastante elucidativo é o ofício datado de 21 de março de 1834, no qual o presidente Manoel José Pires da Silva Pontes ordenava ao juiz de paz que ele parasse de "violentar" os índios, obrigando-os a levarem ofícios a Vitória. Recomendava que para esse serviço extraordinário deveriam ser contratados "caminheiros", abonando-os com a quantia que fosse de "razão". ${ }^{23} \mathrm{Ou}$, ainda, a correspondência de 23 de maio de 1837, na qual o presidente inquire o juiz de paz de Nova Almeida se ele já havia procedido ao sumário de culpa do soldado de polícia José Joaquim dos Reis por ter "cometido insultos e violências" contra os índios. ${ }^{24}$

Apenas $8 \%$ das ocorrências são sobre rebelião, isto é, dois documentos. No primeiro, José Francisco Andrade e Almeida Monjardim, em exercício no cargo de presidente da província em 1831, mandou o capitão-mor das ordenanças da vila de Nova Almeida tomar providências contra os índios que "espalham boatos 
ameaçadores e aterradores de lançarem fora os brancos [...] fazendo conhecer a esta gente ignorante que serão castigados [...] no rigor das leis". ${ }^{25}$ Além disso, o presidente ainda recomendou ao capitão-mor que empenhasse todo o seu "zelo para dissuadi-los e informá-los a respeito das leis e das autoridades constituídas". ${ }^{26}$ Em outro documento enviado ao capitão-mor, solicita que se mande o juiz proceder a uma "inquisição" sobre o caso e, mais ainda, que fossem processados os cabeças da rebelião dos índios. ${ }^{27}$

$\mathrm{O}$ conjunto de documentos a partir dos quais se aufere o tipo de ação realizada pelos índios no período em foco aponta, com muita clareza, que eles negociavam com as autoridades seus interesses e, mais que isso, dentro dos limites da legalidade. Isso não excluía, no entanto, ações individuais ou coletivas que, aos olhos das autoridades, eram consideradas ilegais, como a fuga do posto de trabalho ou a rebelião coletiva contra os brancos. Não é pretensão deste artigo explorar a rebelião dos índios de Nova Almeida que, pelas poucas indicações presentes, provavelmente, relacionava-se com o progressivo avanço dos "brancos" sobre suas terras. Importante frisar, contudo, que os índios participavam da sociedade imperial capixaba não apenas como mão de obra, trabalhando a serviço do império e da nação, mas também agindo a favor de seus próprios interesses, tal como fica demonstrado em suas fugas, seus requerimentos e suas rebeliões.

\section{Considerações finais: trabalho e fronteiras étnicas}

O Espírito Santo oitocentista foi uma região do império bastante indígena. Não apenas no sentido mais frequentemente estudado e aceito pela historiografia, isto é, como uma província que abrigava muitas tribos de índios puris e botocudos em suas matas e sertões. A província foi uma região muito indígena também porque os índios atuavam no cotidiano de sua vida social e política, contribuindo para moldar e desenvolver a vida local, juntamente com os brancos, os pardos, os pretos e os escravos.

As estatísticas oficiais elaboradas no período e os diferentes testemunhos históricos sobre a região durante a primeira metade 
do século XIX demonstram que os índios representavam uma fatia da população importante para a estruturação e o funcionamento da vida local. A preocupação das autoridades em organizá-los e controlá-los, inserindo-os de modo compulsório na economia local, não foi, por isso mesmo, uma ação esporádica ou feita ao acaso das circunstâncias. Bem ao contrário, essa ação das autoridades provinciais foi sistemática e de longa duração, demonstrando que a organização social e política das vilas e lugares indígenas estava sistematizada segundo regras e costumes instituídos ainda no período colonial.

O serviço prestado pelos índios ao império e à nação não esgota, de modo algum, a contribuição do trabalho dos índios para a estruturação da economia e da sociedade local. Ao longo do texto, foi frisado que eles também eram obrigados a trabalhar para si e para os particulares, dimensões importantes para se compreender os diferentes processos de inserção dos indígenas no mundo social dominante, mas que, nos limites desta reflexão, não foi possível explorar. Apesar disso, não é demais lembrar que esses dados sugerem duas situações: que os índios trabalhavam para os particulares, tanto no meio rural como nos estabelecimentos urbanos; e que eles também eram responsáveis por parte da economia regional camponesa, especialmente aquela existente antes do ingresso dos imigrantes italianos e alemães no Espírito Santo, e que era exercida pelos seguimentos pobres e livres da província. Ambas as questões, no entanto, ainda não foram enfrentadas pela historiografia sobre a região.

Em suma, existiu no Espírito Santo um ativo aparato administrativo voltado para obtenção e organização do trabalho dos índios para o Estado. Esse sistema foi montado segundo as regras instituídas pela carta régia de 12 de maio de 1798 e adaptado às novas condições políticas e institucionais do período pós-Independência, demonstrando que as leis e práticas coloniais com relação aos índios durou muito na província do Espírito Santo. Mais ainda, o interesse pelo trabalho dos índios e o sistema governativo e administrativo criado para garantir a captação deles para o mundo do trabalho acabou reforçando as fronteiras étnicas entre eles e os outros, apesar de o discurso oficial do império pregar a igualdade jurídica dos índios 
com relação aos demais cidadãos e, mais que isso, incentivar a miscigenação e assimilação social deles sem diferença com relação aos demais brasileiros.

Como bem argumentou Fredrik Barth (1998), a etnicidade é um processo histórico-social relacional. Ocorre, portanto, entre grupos sociais que estão em contato e interação, quando se atribui e/ou assume-se uma identidade étnica, isto é, uma identidade baseada na presunção de uma origem comum, criando-se, desse modo, fronteiras étnicas (e sociais) entre os grupos sociais (BARTH, 1998, p. 195). Mas como ainda observou o autor, onde indivíduos e grupos de culturas diversas então em interação, a expectativa é a de que, ao longo do tempo, desenvolva-se "uma congruência de códigos e valores - uma similaridade ou comunidade de cultura. [...] Assim, a persistência de grupos étnicos em contato implica critérios e sinais de identificação, mas igualmente uma estruturação da interação que permite a persistência das diferenças culturais" (BARTH, 1998, p. 196-197).

Essas ponderações de Fredrik Barth são fundamentais para se começar a destrinchar o problema sobre como e por que determinados setores da população indígena do império foram progressivamente adotando outras identidades, como de "cidadão" e "lavrador", ou sendo classificados segundo outras categorias sociais, como "trabalhador" ou "vadio", por exemplo, enquanto outros indivíduos e grupos continuaram sendo etique-tados como "índios" e vivendo primordialmente segundo essa condição étnica e social. No âmbito deste artigo, restringi a análise sobre o impacto da carta régia de 12 de maio de 1798 e do sistema político e administrativo criado à sua sombra no Espírito Santo, pois foi esse sistema político-social que estimulou e reproduziu as fronteiras étnicas entre os "índios" e os "outros" na província. Em outras palavras, o interesse do Estado em obter a mão de obra indígena incentivou a reprodução das fronteiras étnicas na vila de Nova Almeida. Da parte dos índios, contudo, a documentação sugere outro ponto. Ao que tudo indica, era o desejo de manter as terras que legalmente possuíam que os estimulava a assumir socialmente a identidade indígena, mesmo que isso significasse ficar a serviço do império e da nação. 
Outra conclusão decisiva que se pode tirar do material analisado nos gráficos e tabelas deste artigo é a de que, ao mesmo tempo em que as fontes atestam a existência e a eficácia de um sistema montado para a extração do trabalho indígena, a instituição estava caindo em desuso durante o regime imperial. Afinal, à proporção que se avançou para a metade do século, houve uma profunda redução do uso da estrutura política e administrativa da vila para controlar a força de trabalho indígena. Mas é muito importante que se perceba que isso não quer dizer que o Estado cessou de requisitar o trabalho dos índios e menos ainda que eles tenham "desaparecido" da história e da sociedade. O que estava em processo de extinção não eram os índios de Nova Almeida nem o uso de seu trabalho, mas as formas coloniais de classificação social e governança.

\section{Serving the empire and the nation: Indian labor and ethnic boundaries in Espírito Santo (1822-1860)}

Abstract: The paper intends to analyze Indian's political and social organization within the province of Espírito Santo and the process of recruiting Indian labor force to work for the State during the first half of the XIX ${ }^{\text {th }}$ century. Our reflection has two major objectives: 1) analyze the political-administrative system that controlled Indian labor, identifying the places and kinds of jobs performed by them, the main civil and military authorities responsible for Indian issues, and the themes and issues that were currently debated by the Indians, who were being recruited to the imperial and national service; 2) consider the impact this political-administrative system created to recruit Indian labor had in the reproduction of ethnic boundaries between Indian and "other" inhabitants within the province.

Keywords: Indians. Labor. Ethnic boundaries. City government. Espírito Santo province. 


\section{Tabelas:}

\section{Tabela 1 - População da província do Espírito Santo e sertões do rio Doce na década de 1820.}

\begin{tabular}{|c|c|c|c|c|c|}
\hline \multirow[t]{3}{*}{ Localidade } & \multicolumn{4}{|c|}{ Extratos e condição civil da população } & \multirow[t]{3}{*}{ Total } \\
\hline & & Livres & Escravos & Independentes & \\
\hline & Brancos & Índios Pardos Pretos & Pardos Pretos & Índios & \\
\hline Província & 8.094 & $\begin{array}{lll}5.788 & 5.601 & 2.682\end{array}$ & $3.287 \quad 9.901$ & & 35.353 \\
\hline $\begin{array}{l}\text { Sertão do } \\
\text { rio Doce }\end{array}$ & & & & 20.000 & 20.000 \\
\hline Total & & & & & 55.353 \\
\hline
\end{tabular}

Fonte: Vasconcelos (1828); Mattos (2004) 


\section{Tabela 2 - Assuntos indígenas tratados na correspondência oficial entre os presidentes da província do Espírito Santo e as autoridades civis e militares da vila de Nova Almeida, no período entre 1828 e 1853.}

\begin{tabular}{|c|c|c|c|c|c|c|c|c|c|}
\hline \multirow[t]{2}{*}{ Assuntos } & \multicolumn{8}{|c|}{ Intervalos de anos } & \\
\hline & \multicolumn{8}{|c|}{$\begin{array}{l}1828-1831-1834-1837-1840-1843-1846-1849-1852 \\
1830-1833-1836-1839-1842-1845-1848-1851-1853\end{array}$} & Total (\%) \\
\hline Trabalho & 34 & 8 & 3 & 5 & & & & & $\begin{array}{c}50 \\
(58,8 \%)\end{array}$ \\
\hline Terra & & 1 & 2 & $2^{*}$ & $7^{* *}$ & 2 & 3 & 3 & $\begin{array}{c}20 \\
(23,5 \%)\end{array}$ \\
\hline $\begin{array}{l}\text { Reivindicações } \\
\text { dos índios }\end{array}$ & 3 & & 1 & 1 & & & & & $\begin{array}{l}5^{* * *} \\
(5,9 \%)\end{array}$ \\
\hline Outros & 2 & 5 & 1 & 1 & 1 & & & & $\begin{array}{c}10 \\
(11,7 \%)\end{array}$ \\
\hline Total & 39 & 14 & 7 & 9 & 8 & 2 & 3 & 3 & $\begin{array}{c}85 \\
(99,9 \%)\end{array}$ \\
\hline
\end{tabular}

Fonte: Arquivo Público do Estado do Espírito Santo, Série 751, Livro 171 - "Este livro há de servir para o registro da correspondência deste governo com as autoridades civis e militares da vila de Nova Almeida"; Série 751, Livro 172 - "Este livro há de servir para o Registro da correspondência deste Governo com as autoridades civis e militares da vila de Nova Almeida"; Série 751, Livro 181 - "Há de servir este livro para o registro da correspondência com as câmaras municipais das vilas da Serra, Nova Almeida, Linhares, Barra de São Matheus e São Matheus."; Série 751, 182 - "Servirá este livro para o registro da correspondência com todas as câmaras municipais do Norte da Província".

* Os dois documentos referem-se a requerimentos de índios reivindicando a devolução de suas terras.

** Dentre os sete documentos, quatro referem-se a requerimentos de índios reivindicando as terras. 


\section{Tabela 3 - Autoridades civis e militares da vila de Nova Almeida responsáveis pelos assuntos indígenas no período entre 1828 e 1853.}

\begin{tabular}{|c|c|c|c|c|c|c|c|c|}
\hline \multirow[t]{2}{*}{ Autoridades } & \multicolumn{7}{|c|}{ Intevalos de Anos } & \\
\hline & \multicolumn{7}{|c|}{$\begin{array}{l}1828-1831-1834-1837-1840-1843-1846-1849-1852 \\
1830-1833-1836-1839-1842-1845-1848-1851-1853\end{array}$} & $\begin{array}{l}\text { Total } \\
(\%)\end{array}$ \\
\hline Capitão-mor* & 24 & 10 & & & & & & $\begin{array}{c}34 \\
(40 \%)\end{array}$ \\
\hline Sargento-mor & 6 & & & & & & & $\begin{array}{c}6 \\
(7 \%)\end{array}$ \\
\hline Juiz ordinário & 2 & & & & & & & $\begin{array}{c}2 \\
(2,3 \%)\end{array}$ \\
\hline Juiz de paz & 3 & 3 & 5 & 9 & 3 & & & $\begin{array}{c}23 \\
(27 \%)\end{array}$ \\
\hline Câmara** & & 1 & 2 & & 3 & 3 & 3 & $\begin{array}{c}14 \\
(16,5 \%)\end{array}$ \\
\hline Outros & 4 & & & & 2 & & & $\begin{array}{c}6 \\
(7 \%)\end{array}$ \\
\hline Total & 39 & 14 & 7 & 9 & 8 & 3 & 3 & $\begin{array}{c}85 \\
(99,8 \%)\end{array}$ \\
\hline
\end{tabular}

Fonte: Arquivo Público do Estado do Espírito Santo, Série 751, Livro 171 - "Este livro há de servir para o registro da correspondência deste governo com as autoridades civis e militares da vila de Nova Almeida"; Série 751, Livro 172 - "Este livro há de servir para o Registro da correspondência deste Governo com as autoridades civis e militares da vila de Nova Almeida"; Série 751, Livro 181 - "Há de servir este livro para o registro da correspondência com as câmaras municipais das vilas da Serra, Nova Almeida, Linhares, Barra de São Matheus e São Matheus."; Série 751, 182 - "Servirá este livro para o registro da correspondência com todas as câmaras municipais do Norte da Província".

* As correspondências enviadas ao "capitão-mor", "capitão-mor de ordenanças" ou "comandante da ordenança”" estão todas arroladas nesta linha.

** As correspondências enviadas à "câmara" e a "presidente e vereadores da câmara" ou ao "presidente da câmaras" estão todas arroladas nesta linha. 


\section{Tabela 4 - Relação entre os assuntos e as autoridades civis e militares da vila de Nova Almeida, no período entre 1828 e 1853.}

\begin{tabular}{|c|c|c|c|c|c|}
\hline \multirow[t]{2}{*}{ Autoridades } & \multicolumn{4}{|c|}{ Assuntos } & \\
\hline & Trabalho & Terra & $\begin{array}{c}\text { Revindicações dos } \\
\text { índios }\end{array}$ & Outros & $\begin{array}{c}\text { Total } \\
(\%)\end{array}$ \\
\hline Capitão-mor* & 31 & & 1 & 2 & $\begin{array}{c}34 \\
(40 \%)\end{array}$ \\
\hline Sargento-mor & 6 & & & & $\begin{array}{c}6 \\
(7 \%)\end{array}$ \\
\hline Juiz ordinário & 1 & & 1 & & $\begin{array}{c}2 \\
(2,4 \%)\end{array}$ \\
\hline Juiz de paz & 8 & 4 & 3 & 8 & $\begin{array}{c}23 \\
(27 \%) \\
\end{array}$ \\
\hline Câmara ${ }^{* *}$ & & 14 & & & $\begin{array}{c}14 \\
(16,5 \%)\end{array}$ \\
\hline Outros & 4 & 2 & & & $\begin{array}{c}6 \\
(7 \%) \\
\end{array}$ \\
\hline $\begin{array}{l}\text { Total } \\
(\%)\end{array}$ & $\begin{array}{c}50 \\
(58,8 \%)\end{array}$ & $\begin{array}{c}20 \\
(23,5 \%)\end{array}$ & $\begin{array}{c}5^{* * *} \\
(5,9 \%)\end{array}$ & $\begin{array}{c}10 \\
(11,7 \%)\end{array}$ & $\begin{array}{c}85 \\
(99,9 \%)\end{array}$ \\
\hline
\end{tabular}

Fonte: Arquivo Público do Estado do Espírito Santo, Série 751, Livro 171 - "Este livro há de servir para o registro da correspondência deste governo com as autoridades civis e militares da vila de Nova Almeida"; Série 751, Livro 172 - "Este livro há de servir para o Registro da correspondência deste Governo com as autoridades civis e militares da vila de Nova Almeida"; Série 751, Livro 181 - "Há de servir este livro para o registro da correspondência com as câmaras municipais das vilas da Serra, Nova Almeida, Linhares, Barra de São Matheus e São Matheus."; Série 751, 182 - "Servirá este livro para o registro da correspondência com todas as câmaras municipais do Norte da Província".

* As correspondências enviadas ao "capitão-mor", "capitão-mor das ordenanças" e "comandante da ordenança" estão todos arrolados nesta linha.

** As correspondências enviadas à "câmara", ao "presidente e vereadores da câmara" ou ao "presidente da câmara" estão todas arroladas nesta linha.

*** Este resultado não inclui os seis documentos onde há referência de índios reivindicando suas terras por meio de requerimentos ou representações, que foram arrolados na coluna "Terra". 


\section{Tabela 5 - Tipos de ocorrência no assunto "trabalho" presentes na correspondência oficial entre os presi- dentes da província do Espírito Santo e as autori- dades civis e militares da vila de Nova Almeida, no período entre 1828 e 1853.}

\begin{tabular}{c|c}
\hline Tipos de ocorrência no assunto "trabalho" & $\begin{array}{c}\text { Número de } \\
\text { ocorrências (\%) }\end{array}$ \\
\hline $\begin{array}{c}\text { Solicitação e/ou substituição de índios para o serviço } \\
\text { imperial }\end{array}$ & $41(70,7 \%)$ \\
\hline $\begin{array}{c}\text { Prisão por deserção ao trabalho e/ou notificação de } \\
\text { deserção }\end{array}$ & $4(6,9 \%)$ \\
\hline $\begin{array}{c}\text { Remuneração de trabalho realizado } \\
\text { Organização do processo de recrutamento para o serviço } \\
\text { imperial e nacional }\end{array}$ & $2(3,4 \%)$ \\
\hline Outros & $3(5,1 \%)$ \\
\hline Total & $58(99,9 \%)$ \\
\hline
\end{tabular}

Fonte: Arquivo Público do Estado do Espírito Santo, Série 751, Livro 171 - "Este livro há de servir para o registro da correspondência deste governo com as autoridades civis e militares da vila de Nova Almeida"; Série 751, Livro 172 - "Este livro há de servir para o Registro da correspondência deste Governo com as autoridades civis e militares da vila de Nova Almeida"; Série 751, Livro 181 - "Há de servir este livro para o registro da correspondência com as câmaras municipais das vilas da Serra, Nova Almeida, Linhares, Barra de São Matheus e São Matheus."; Série 751, 182 - "Servirá este livro para o registro da correspondência com todas as câmaras municipais do Norte da Província”.

Observação: um mesmo documento compulsado pode possuir mais de uma ocorrência. 


\section{Tabela 6 - Tipos ou lugares de trabalho citados na corres- pondência oficial entre os presidentes da província do Espírito Santo e as autoridades civis e militares da vila de Nova Almeida, no período entre 1828 e 1853.}

\begin{tabular}{c|c}
\hline Tipos ou lugares de trabalho & $\begin{array}{c}\text { Número de ocorrências } \\
(\mathbf{\%})\end{array}$ \\
\hline Serviço imperial e nacional & $11(22 \%)$ \\
\hline Serviço público e/ou obras públicas & $5(10 \%)$ \\
\hline Escaler do governo e passagens & $5(10 \%)$ \\
\hline Forte São João e passagens & $6(12 \%)$ \\
\hline Diretoria do Rio Doce & $8(16 \%)$ \\
\hline Combate a quilombos ou resgate de escravos \\
fugitivos & $3(6 \%)$ \\
\hline Corte de madeira e construção de escuna & $4(8 \%)$ \\
\hline Outros & $8(16 \%)$ \\
\hline Total & $50(100 \%)$ \\
\hline
\end{tabular}

Fonte: Arquivo Público do Estado do Espírito Santo, Série 751, Livro 171 - "Este livro há de servir para o registro da correspondência deste governo com as autoridades civis e militares da vila de Nova Almeida"; Série 751, Livro 172 - "Este livro há de servir para o Registro da correspondência deste Governo com as autoridades civis e militares da vila de Nova Almeida"; Série 751, Livro 181 - "Há de servir este livro para o registro da correspondência com as câmaras municipais das vilas da Serra, Nova Almeida, Linhares, Barra de São Matheus e São Matheus."; Série 751, 182 - "Servirá este livro para o registro da correspondência com todas as câmaras municipais do Norte da Província".

Observação: um mesmo documento compulsado pode possuir mais de uma ocorrência. 


\section{Tabela 7 - Tipos de ação dos índios inferidos ou citados na correspondência oficial entre os presi- dentes da província do Espírito Santo e as autori- dades civis e militares da vila de Nova Almeida, no período entre 1828 e 1853.}

\begin{tabular}{c|c}
\hline Tipos de ação dos índios & $\begin{array}{c}\text { Número de ocorrências } \\
(\%)\end{array}$ \\
\hline Rebelião & $2(8 \%)$ \\
\hline Fuga e deserção do trabalho & $4(16 \%)$ \\
\hline Requerimento ou representação às autoridades* & $11(44 \%)$ \\
\hline Queixas & $8(32 \%)$ \\
\hline Total & $25(100 \%)$ \\
\hline
\end{tabular}

Fonte: Arquivo Público do Estado do Espírito Santo, Série 751, Livro 171 - "Este livro há de servir para o registro da correspondência deste governo com as autoridades civis e militares da vila de Nova Almeida"; Série 751, Livro 172 - "Este livro há de servir para o Registro da correspondência deste Governo com as autoridades civis, e militares da vila de Nova Almeida"; Série 751, Livro 181 - Há de servir este livro para o registro da correspondência com as câmaras municipais das vilas da Serra, Nova Almeida, Linhares, Barra de São Matheus e São Matheus."; Série 751, 182 - "Servirá este livro para o registro da correspondência com todas as câmaras municipais do Norte da Província".

Observação: um mesmo documento compulsado pode possuir mais de uma ocorrência.

* Foram contabilizadas nesta linha todas as ocorrências de requerimentos ou representações, inclusive os seis requerimentos referentes a terras ou terrenos, que na Tabela 2 foram arrolados na linha "Terra". 
A serviço do império e da nação:...

\section{Gráficos:}

\section{Gráfico 1 \\ População Livre segundo grupos étnico-raciais}

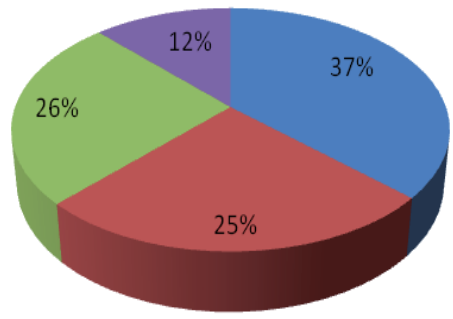

Brancos

• Índios

- Pardos

- Pretos

Fonte: Tabela 1.

Gráfico 2

População total segundo condição civil

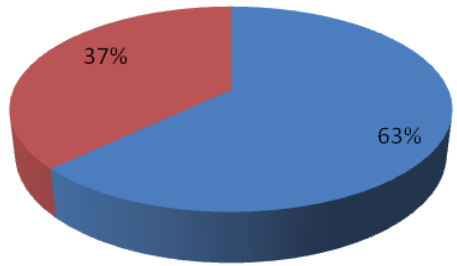

- Livres

- Escravos

Fonte: Tabela 1.

Anos 90, Porto Alegre, v. 17, n. 31, p. 13-55, jul. 2010 


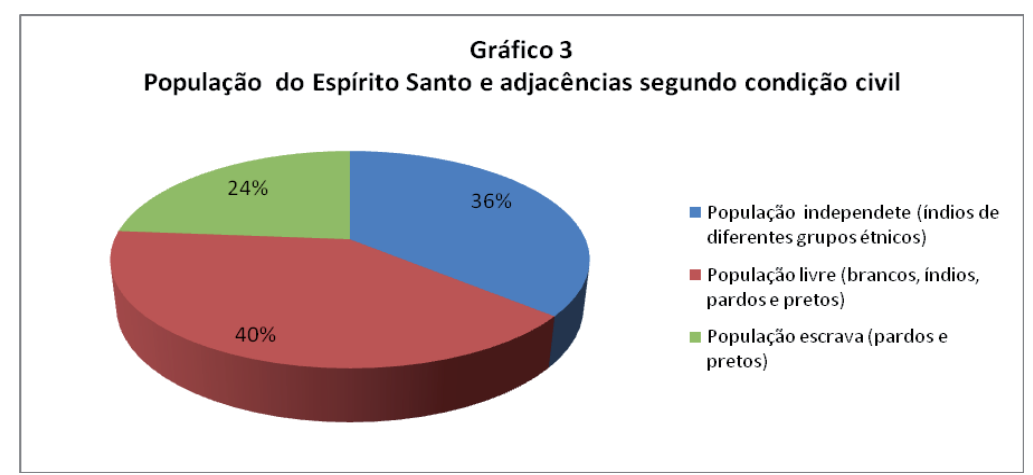

Fonte: Tabela 1.

\section{Gráfico 4}

População indígena do Espírito Santo e adjacências com relação aos outros extratos

- Índios (independentes e súditos do império) a outros (livres e escravos)

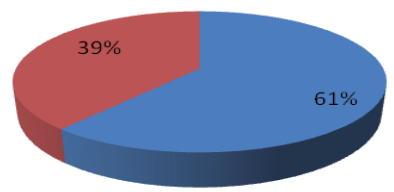

Fonte: Tabela 1. 
A serviço do império e da nação:...

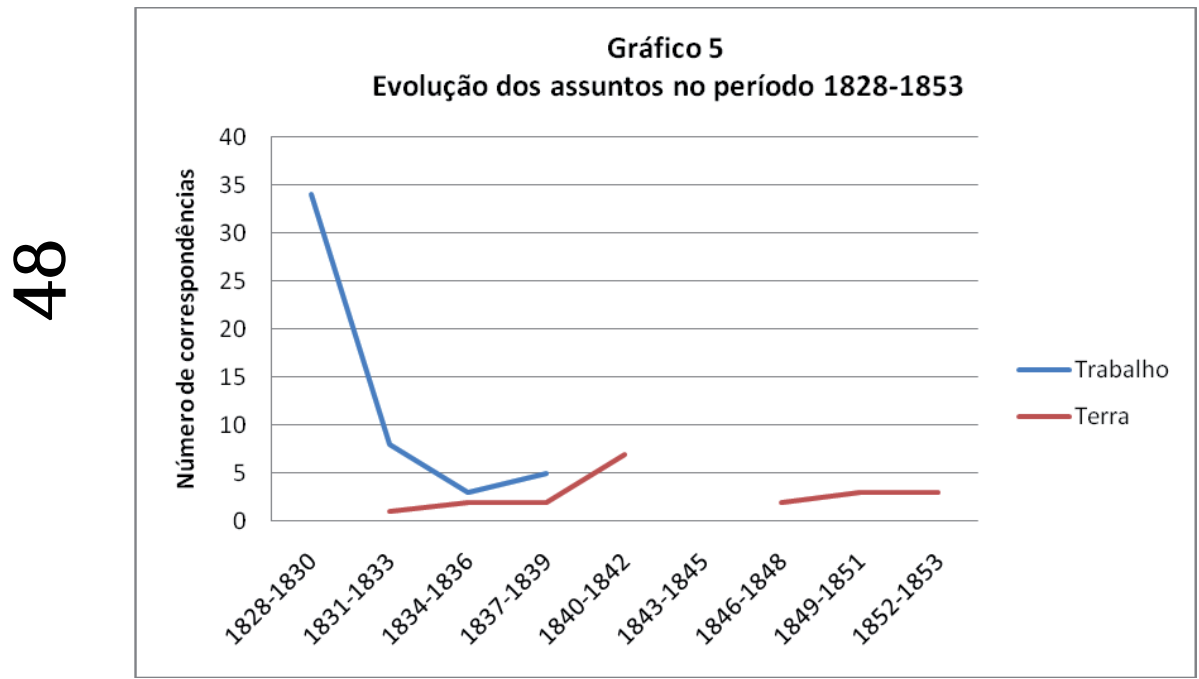

Fonte: Tabela 2.

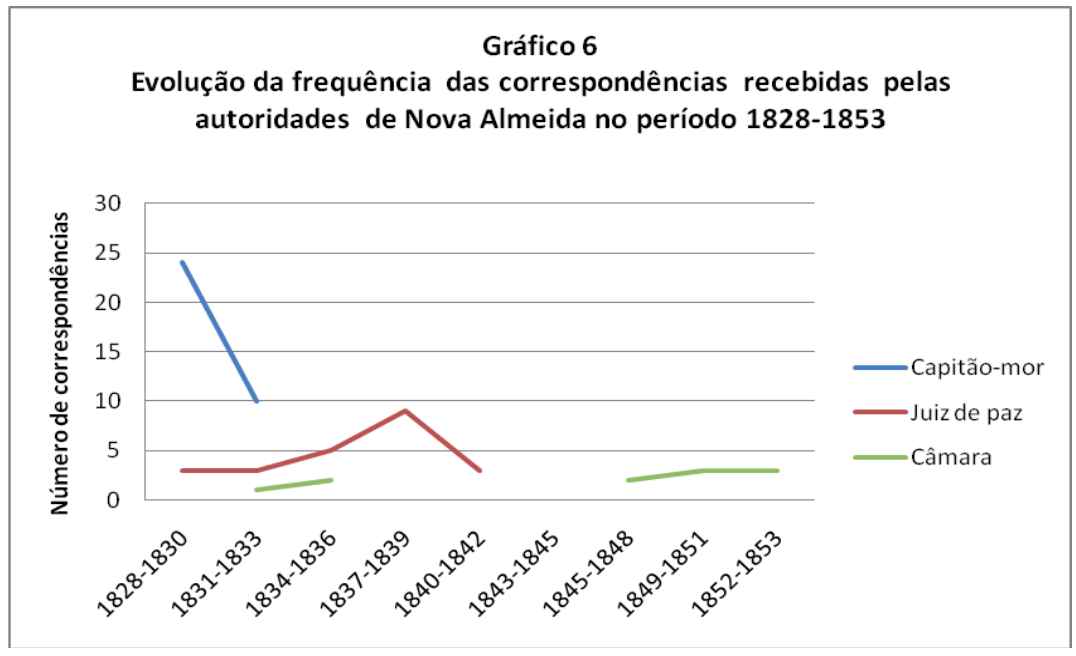

Fonte: Tabela 3.

Anos 90, Porto Alegre, v. 17, n. 31, p. 13-55, jul. 2010 


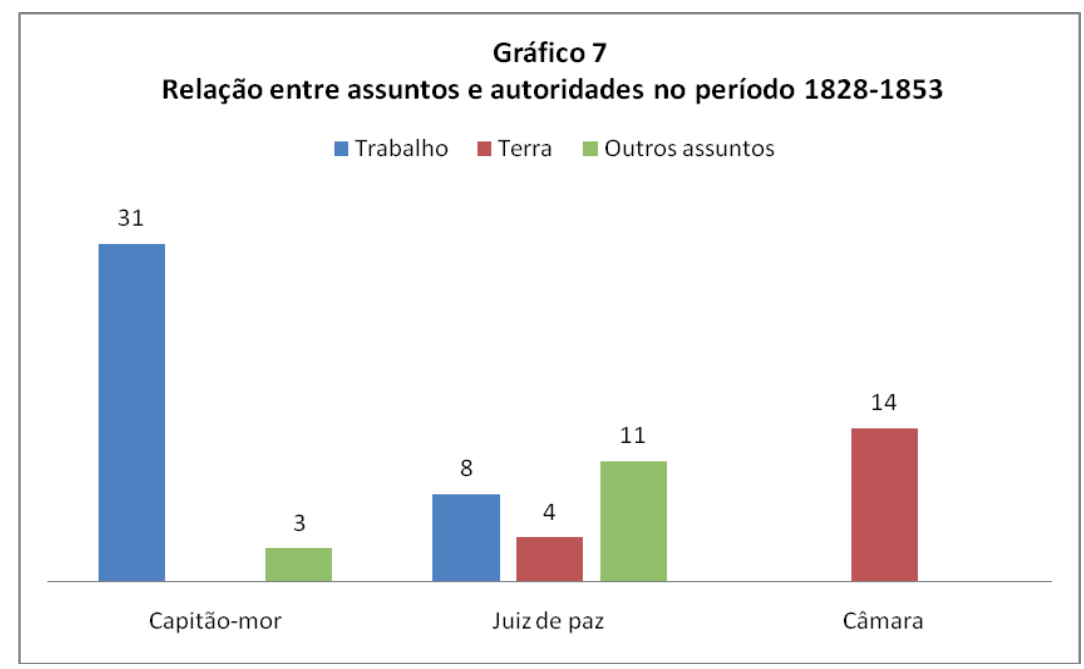

Fonte: Tabela 4.

\section{Gráfico 8}

Tipos de ocorrências no assunto "trabalho" presentes na correspondência ofical no período 1828-1853

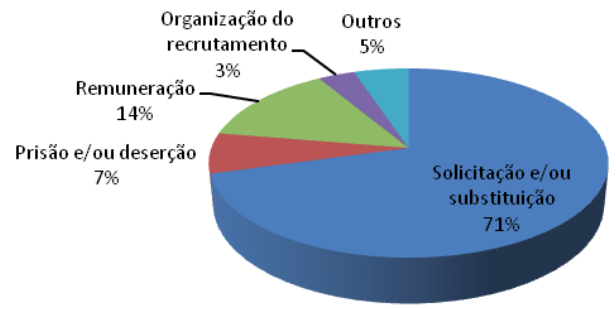

Fonte: Tabela 5.

Anos 90, Porto Alegre, v. 17, n. 31, p. 13-55, jul. 2010 
A serviço do império e da nação:...

\section{Gráfico 9 \\ Ocorrências de lugares e tipos de trabalho na correspondência oficial no período $1828-1853$}

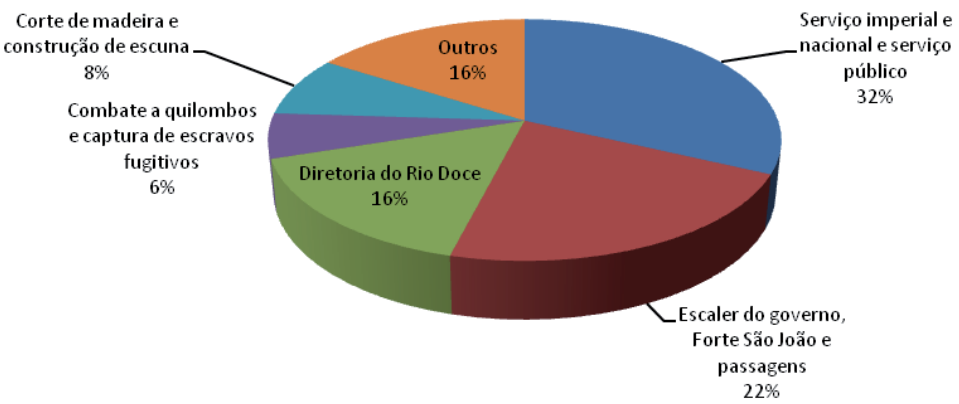

Fonte: Tabela 6.

\section{Gráfico 10}

Tipos de ação dos índios presentes na correspondência oficial no período $1828-1853$

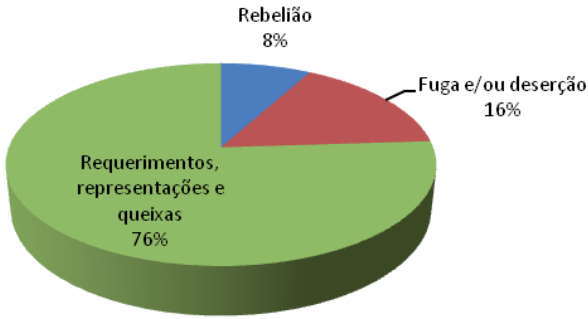

Fonte: Tabela 7.

Anos 90, Porto Alegre, v. 17, n. 31, p. 13-55, jul. 2010 


\section{Vânia Maria Losada Moreira}

\section{Notas}

${ }^{1}$ Arquivo Público do Estado do Espírito Santo. Série 751, Livro 171, 11/07/1828, p. 4v-5. Nas citações de trechos de documentos antigos, a grafia foi atualizada segundo as normas ortográficas vigentes.

${ }^{2}$ Arquivo Público do Estado do Espírito Santo. Série 751, Livro 171, 15/06/1829, p. 23.

3 "Diretório que se deve observar nas povoações dos índios do Pará e do Maranhão enquanto sua majestade não mandar o contrário" (ALMEIDA, R. H., 1997, Apêndice, p. 1-41).

${ }^{4}$ Cf. "Carta Régia de 12 de maio de 1798 sobre a civilização dos índios" (RUBIM, 1856, p. 313-325).

${ }^{5}$ Ver a Tabela 2 e o Gráfico 5 deste artigo, onde fica registrado que a requisição de índios para o trabalho público é o principal assunto tratado entre os presidentes da província do Espírito Santo e as autoridades civis e militares de Nova Almeida até 1839. A partir dessa data, temas e assuntos relacionados às terras indígenas adquirem o primeiro plano.

${ }^{6}$ Para uma discussão da ideia de autogoverno dentro da tradição corporativista portuguesa, cf. Hespanha e Xavier ([s.d.], p. 123-124) e Monteiro, N. ([s.d.], p. 316). Sobre a aclimatação de ideias e instituições do Antigo Regime no Brasil, cf. Fragoso, Gouvea e Bicalho (2001, p. 21).

${ }^{7}$ Arquivo Público do Estado do Espírito Santo, Série 751, Livro 171 - "Este livro há de servir para o registro da correspondência deste governo com as autoridades civis e militares da vila de Nova Almeida"; Série 751, Livro 172 - "Este livro há de servir para o registro da correspondência deste governo com as autoridades civis e militares da vila de Nova Almeida"; Série 751, Livro 181 - "Há de servir este livro para o registro da correspondência com as câmaras municipais das vilas da Serra, Nova Almeida , Linhares, Barra de São Matheus, e São Matheus.”; Série 751, Livro 182 - "Servirá este livro para o registro da correspondência com todas as câmaras municipais do Norte da Província".

${ }^{8}$ Estimei o número de correspondências em cada livro a partir do seguinte método: nos livros, são usadas a frente e o verso das folhas para armazenar as correspondências, mas só a frente recebe uma numeração. De modo geral, cada correspondência ocupa a frente e metade do verso da folha. Com esses dados, estimei que as 66 correspondências que citavam os índios no livro 171, com 116 folhas (ou 232 páginas), correspondiam a 41,5\% do total das correspondências. Apliquei o mesmo método para estimar o número de correspondências do livro 172 (85 folhas ou 170 páginas), do livro 181 (150 folhas ou 300 páginas) e do livro 182 (115 folhas ou 230 páginas).

Anos 90, Porto Alegre, v. 17, n. 31, p. 13-55, jul. 2010 
${ }^{9}$ Importante frisar, contudo, que a documentação compulsada versa sobre um conjunto variado de temas e problemas. Mas apesar da importância desses temas, eles não serão analisados neste texto, pois, para serem bem entendidos e explorados, demandam muito mais espaço do que se dispõe agora. Nos limites desta reflexão, portanto, tratarei fundamentalmente do universo relativo ao trabalho indígena, tema central deste artigo.

${ }^{10}$ Arquivo Público do Estado do Espírito Santo. Série 751, Livro 171, 02/04/1830, p. $35 \mathrm{v}$.

${ }^{11}$ Arquivo Público do Estado do Espírito Santo. Série 751, Livro 171, 26/01/1830, p. $33 \mathrm{v}$.

${ }^{12}$ Arquivo Público do Estado do Espírito Santo. Série 751, Livro 171, 17/09/1828, p. $8-8 \mathrm{v}$.

${ }^{13}$ Arquivo Público do Estado do Espírito Santo. Série 751, Livro 171, 21/01/1829, p. 16.

${ }^{14}$ Arquivo Público do Estado do Espírito Santo. Série 751, Livro 171, 19/08/1830, p. 40.

${ }^{15}$ Arquivo Público do Estado do Espírito Santo. Série 751, Livro 171, 27/11/1828, p. $9 \mathrm{v}-10$.

${ }^{16}$ Cf., respectivamente, Arquivo Público do Estado do Espírito Santo. Série 751, Livro 171, 15/06/1829, p. 23; e Arquivo Público do Estado do Espírito Santo. Série 751, Livro 171, 21/03/1834, p. 72-72v.

${ }^{17}$ Arquivo Público do Estado do Espírito Santo. Série 751, Livro 171, 15/12/1829, p. 30 .

${ }^{18}$ Arquivo Público do Estado do Espírito Santo. Série 751, Livro 171, 23/12/1829, p. $31 \mathrm{v}$.

${ }^{19}$ Arquivo Público do Estado do Espírito Santo. Série 751, Livro 171, 09/06/1836, p. 100.

${ }^{20}$ Arquivo Público do Estado do Espírito Santo. Série 751, Livro 171, 20/11/1837, p. $114 \mathrm{v}$.

${ }^{21}$ Arquivo Público do Estado do Espírito Santo. Série 751, Livro 171, 19/08/1843, p. 73.

${ }^{22}$ Arquivo Público do Estado do Espírito Santo. Série 751, Livro 171, 23/08/1838, p. 14.

${ }^{23}$ Arquivo Público do Estado do Espírito Santo. Série 751, Livro 171, 21/03/1834, p. 72-72v.

${ }^{24}$ Arquivo Público do Estado do Espírito Santo. Série 751, Livro 171, 23/05/1837, p. 112.

${ }^{25}$ Arquivo Público do Estado do Espírito Santo. Série 751, Livro 171, 11/11/1831, p. 52. 
${ }^{26}$ Arquivo Público do Estado do Espírito Santo. Série 751, Livro 171, 11/11/1831, p. 52.

${ }^{27}$ Arquivo Público do Estado do Espírito Santo. Série 751, Livro 171, 11/11/1831, p. $52 \mathrm{v}$

\section{Referências}

ALMADA, V. Escravismo e transição: o Espírito Santo. Rio de Janeiro: Graal, 1984.

ALMEIDA, M. R. C. Metamorfoses indigenas: identidade e cultura nas aldeias coloniais do Rio de Janeiro. Rio de Janeiro: Arquivo Nacional, 2003.

ALMEIDA, R. H. de. O diretório dos indios: um projeto de "civilização" no Brasil do século XVIII. Brasília: Ed. Universidade de Brasília, 1997.

BARTH, F. Grupos étnicos e suas fronteiras. In: POUTIGNAT, Philippe; STREIFFFENART, J. (Org.). Teorias da etnicidade. São Paulo: Fundação Editora da Unesp, p. 185-227, 1998.

COUTINHO, D. J. C. da S. Apontamentos secretos sobre a visita de 1811 e 1812. Vista de 1819-1820. In: NEVES, L. G. S. (Org.). O Espirito Santo em princípio do século XIX: apontamentos feitos pelo bispo do Rio de Janeiro à capitania do Espírito Santo nos anos de 1812 e 1819. Vitória: Estação Capixaba e Cultural - ES, p. 43-155, 2002.

CUNHA, M. C. da. Política indigenista no século XIX. In: CUNHA, M. C. da (Org.). História dos indios no Brasil. São Paulo: Companhia das Letras: Secretaria Municipal de Cultura: Fapesp, p. 115-174, 1992.

DOMINGUES, A. Quando os indios eram vassalos: colonização e relações de poder no Norte do Brasil, na segunda metade do século XVIII. Lisboa: Comissão Nacional para as Comemorações dos Descobrimentos Portugueses, 2000.

FRAGOSO, J.; GOUVEA, M. de F.; BICALHO, M. F. (Org.). O antigo regime nos trópicos. Rio de Janeiro: Civilização Brasileira, 2001.

HESPANHA, A. M.; XAVIER, A. B. A representação da sociedade e do poder. In: MATTOSO, J. (Dir.). História de Portugal: o Antigo Regime (1620-1807). Lisboa: Editorial Estampa, p. 121-156, s. d.

LEITE, S. História da Companbia de Jesus no Brasil. Rio de Janeiro: Instituto Nacional do Livro; Lisboa: Livraria Portugália, 1945.

MATTOS, I. M. de. Civilização e revolta: os botocudos e a catequese na província de Minas. Bauru: Edusc, 2004. 
MONTEIRO, J. M. Negros da terra: índios e bandeirantes nas origens de São Paulo. São Paulo: Companhia das Letras, 1994.

. Tupis, tapuias e historiadores. Tese (Livre-Docência). Universidade Estadual de Campinas. Campinas, 2001.

MONTEIRO, N. G. Os conselhos e as comunidades. In: MATTOSO, J. (Dir.). História de Portugal: o Antigo Regime (1620-1807). Lisboa: Editorial Estampa, p. 303-331, s. d.

MOREIRA,V. M. L. Índios no Brasil: marginalização social e exclusão historiográfica. Diálogos Latino-americanos, n. 3, p. 87-113, 2001.

Caboclismo, vadiagem e recrutamento militar entre as populações indígenas do Espírito Santo (1822-1875). Diálogos Latino-americanos, n. 11, p. 94-120, 2005.

. História, etnia e nação: o índio e a formação nacional sob a ótica de Caio Prado Júnior. Memoria Americana, n. 16, v. 1, p. 63-84, 2008.

MOREIRA NETO, C. de A. Os indios e a ordem imperial. Brasília: CGDOC/Funai, 2005.

PRADO JÚNIOR, C. Formação do Brasil contemporâneo. 11. ed. São Paulo: Brasiliense, 1971.

RELATORIO com que o Exm. Sr. Barão do Itapemirim, Primeiro Vice-Presidente da província do Espirito Santo entregou a administração da mesma ao Exm. Snr. Dr. Jose Mauricio Fernandes Pereira de Barros no dia 8 de março de 1856. Victoria: Typographia Capitaniense de P. A. d'Azeredo, 1856. Disponível em http:// brazil.crl.edu/bsd/bsd/u129/000002.html Acesso em 1 de mar. 2010.

RELATORIO com que o Exm. Sr. Presidente da Provincia do Espirito Santo o Doutor Jose Mauricio Fernandes Pereira de Barros passou a administração da Provincia, ao Exm. Sr. Comendador Jose Francisco de Andrade Monjardim Segundo Vice-presidente no dia 13 de fevereiro de 1857. Victoria: Typ. Capitaniense de P. A. d'Azeredo, 1857. Disponível em http://brazil.crl.edu/bsd/bsd/u131/000002.html Acesso em 1 de mar. 2010.

RUBIM, F. A. Notas, apontamentos e notícias para a história da província do Espírito Santo. Revista do Instituto Histórico e Geográfico Brasileiro, n. 22, p. 161-348, 1856.

SAINT-HILAIRE, A. de. Viagem ao Espirito Santo e Rio Doce. São Paulo: Edusp, 1974.

SALETO, N. Transição para o trabalho livre e pequena propriedade no Espirito Santo. Vitória: Edufes, 1996 . 
. Trabalhadores nacionais e imigrantes no mercado de trabalho do Espirito Santo. Vitória: Edufes, 1996b.

SAMPAIO, P. M. M. Espelhos partidos: etnia, legislação e desigualdade na colônia. Sertões do Grão-Pará, c.1755-c.18234. Tese (Doutorado em História) - Instituto de Ciências Humanas e Filosofia. Universidade Federal Fluminense. Niterói, 2001. URICOECHEA, F. O minotauro imperial: a burocratização do Estado patrimonial brasileiro no século XIX. Rio de Janeiro: Difel, 1978.

VASCONCELLOS, I. A. de. Memoria statistica da provincia do Espirito Santo escrita no anno de 1828. Vitória: Arquivo Público Estadual, 1978.

Recebido em: 13/03/2010

Aprovado em: 25/04/2010 